\title{
The Effect Of Problem Based Learning With Gallery Walk Strategy To Creativity And Communication Skills
}

\author{
Titin Sunarti \\ Physics Department, \\ Universitas Negeri Surabaya, Surabaya, Indonesia \\ titinsunarti@unesa.ac.id
}

\author{
Dilla Ayu Septiana \\ Physics Department, \\ Universitas Negeri Surabaya, Surabaya, Indonesia \\ dillaseptiana@mhs,.unesa.ac.id
}

\begin{abstract}
This research aimed to analyze the effect of Problem Based Learning with Gallery Walk Strategy to creativity and communication skills in physics. This strategy was effective in a conceptual topic. Therefore in this research, the chosen topic was global warming. This research was conducted on two groups of students that consisted of 30 students. The groups were assumed to have the same level of knowledge and skills. Data was gotten by observation, questionnaire and the learning outcomes. The learning outcome was a poster that was also used as the learning media. The results showed that the implementation of PBL with Gallery Walk strategy was able to enhance the creativity and communication skill of students. Using manual poster was more effective to enhance creativity and communication skills of students.
\end{abstract}

Keywords-problem based learning, gallery walk strategy, creativity, communication skills

\section{INTRODUCTION}

Globalization that has grown rapidly in the 21 st century makes Indonesia's economic growth increased significantly. It has shown the increasingly competitive workforce of the 21 st century in Indonesia. Therefore, individuals are expected to have more skills to survive in the 21 st century, '7Cs Skills'. These skills consist of (1) Critical Thinking and Problem Solving; (2) Creativity and Innovation; (3) Collaboration, teamwork, and leadership; (4) Cross-cultural Understanding; (5) Communication, Information, and Media Literacy; (6) Computing and ICT Literacy; (7) Care and Learning Selfreliance [1]. In other words, globalization also affects the development of Information and Technology (IT). Technology has developed quickly. It makes all human activities can be done on the internet. Moreover, the digital era constrains people by allowing communication through computer technology, not a real person. As the impact, it will lose some humanity or it forms social isolation [2]. The skills, that are important and always be used in daily life, are creativity and communication skill. These skills are so useful in work and daily life.

Previous research conducted by Jellen and Urban revealed that Indonesian students' creativity was still low compared to other countries [3]. Indonesian students' lack of creativity cannot be separated from the educational influences [3]. In a study of elementary school students who were assessed as being gifted, Karnes et al. (1961) found that creativity was related significantly to educational achievement [4]. Educational achievement is the major goal of education. According to Woodman and Schoenfeldt, every student has different creativity from one another [5]. The dimensions of creativity are a process, person and product [6]. For the dimension of the person, it includes creative thinking skills, which consists of fluency, flexibility, originality and elaboration [7]. Torrance also notes several signs that indicate when creative learning occurs, such as improved motivation, alertness, curiosity, concentration, and achievement [8]. Each aspect of creativity has several indicators. The indicators of creative thinking skills are shown in table 1 [7].

TABLE 1. THE INDICATORS OF CREATIVE THINKING SKILLS

\begin{tabular}{|c|c|}
\hline Aspect & Indicator \\
\hline Fluency & $\begin{array}{l}\text { - Ask a lot of questions } \\
\text { - Answer the questions from others } \\
\text { - Express their ideas } \\
\text { - Work faster and do more than other } \\
\text { students } \\
\text { - See the errors and solve it quickly }\end{array}$ \\
\hline Flexibility & $\begin{array}{l}\text { - Provide various interpretations of an } \\
\text { image, video or problem } \\
\text { - Apply the concept or principle in } \\
\text { different ways } \\
\text { - Able to classify things based on the } \\
\text { categories } \\
\text { - Able to change the direction of thinking } \\
\text { - Have different ways to solve the } \\
\text { problems }\end{array}$ \\
\hline Originality & $\begin{array}{l}\text { - Think about the possibilities that others } \\
\text { don't think of a problem } \\
\text { - Have a lot of questions and try to solve it } \\
\text { in different ways } \\
\text { - Able to create a new solution for the } \\
\text { problem }\end{array}$ \\
\hline Elaboration & $\begin{array}{l}\text { - Seek deeper meaning for answer by } \\
\text { carried the detailed steps out } \\
\text { - Develop or enrich other people's ideas }\end{array}$ \\
\hline
\end{tabular}

There are many suggestions in the literature on how to develop creative skills from childhood to adulthood. For example, Karnes et al. suggested that educational programs should be organized flexibly to provide better services, such as enrichment programs, to students. The teaching method that stimulates both convergent and divergent thinking are important for stimulating creative thinking and are more challenging to creative students [4]. Individual assignments base on problem-solving and problem finding also would 
stimulate creativity [4, 9, and 10]. Teachers who enable choose teaching method that can change the divergent thinking of students seem the most effective in stimulating creativity in students [4]. Besides using individual assignments to stimulate creativity, teachers should provide situations for students to participate in group activities $[10,11]$. These group activities, in addition, to enhance creative thinking and academic performance should provide students with opportunities for developing peer acceptance [4]. Based on research by Guilford, most trainings for creativity was aimed to enhance divergent thinking and production skills [12]. One teaching method for developing creativity is a problem-solving approach, which is an indirect teaching method [13].

In the 2013 curriculum, the highlight of instructional methods is the activity and creativity, inspiring, fun, studentcentred, authentic, contextual and meaningful learning [14]. PBL is also one of the teaching models that be suggested to be used in class, especially science. PBL is problem-based learning models that use authentic problems and product as the learning outcomes [15]. The syntax of PBL is (1) orientation to the problem, (2) organize students to learn, (3) assist individual and/or group investigation, (4) develop and present the product and (5) revision and reflection [15]. Based on previous researches in 2018, the results showed that the implementation of PBL was able to improve creative thinking skills student $[16,17]$. To give different experience with a fun atmosphere, this teaching method is implemented using the gallery walk strategy.

The gallery walk is a learning strategy that encourages participants of students to express opinions and ideas with a poster as media $[18,19]$. Gallery walk has some steps, those are (1) determine the topics, (2) divide into small groups, (3) discussion, (4) exhibition and (5) reflection. Based on previous researches, a gallery walk was able to improve the communication and creativity ability of students [20, 21, and 22]. This strategy is effective in the conceptual topic [23, 24]. Therefore in this research, the chosen topic is global warming. Global warming is a conceptual topic that according to be used in PBL with gallery walk strategy [25].

This research aims to analyze the effect of Problem Based Learning with Gallery Walk Strategy to creativity and communication skills in physics. The hypothesis was made that the implementation of PBL with Gallery walk Strategy will be able to improve creativity and communication skills of students.

\section{RESEARCH METHODS}

The research was a quantitative descriptive research with non-equivalent design. Using non-equivalent research design is based on sample selection chosen by group/class (not taken randomly). This research was conducted with two groups of students that consisted of 30 students. The groups were assumed to have the same level of knowledge and skills. It held on even semester of 2018/2019. More specifically, the samples were XI Science 4 and XI Science 5. The chosen topic was global warming. Data were gotten from observation, questionnaire and the learning outcomes. The poster was the learning outcomes and also be used as the learning media.

\section{RESULTS AND DISCUSSION}

The research was conducted in 3 steps. The first step was the preliminary observation. In this step, researchers collected data by pre-observation. The second step, researchers implemented the treatment, PBL with Gallery Walk strategy. In this step, the observer observed and assessed the learning activities in class as post-observation. The last step was the questionnaire and learning outcomes. Observation is one of the efforts to supervise and assess the learning process, which is the dimension of creativity [6]. The results of observation, both pre and post, are described in table 2 .

As the learning outcomes, the product was a poster. Product is one the dimension of creativity [6]. Based on previous research, most of the teachers agreed that the product was the main assessing goal of creativity [4]. The samples of the product are showed in figure 1 and 2, which class 1 chose digital poster and class 2 chose manual poster.

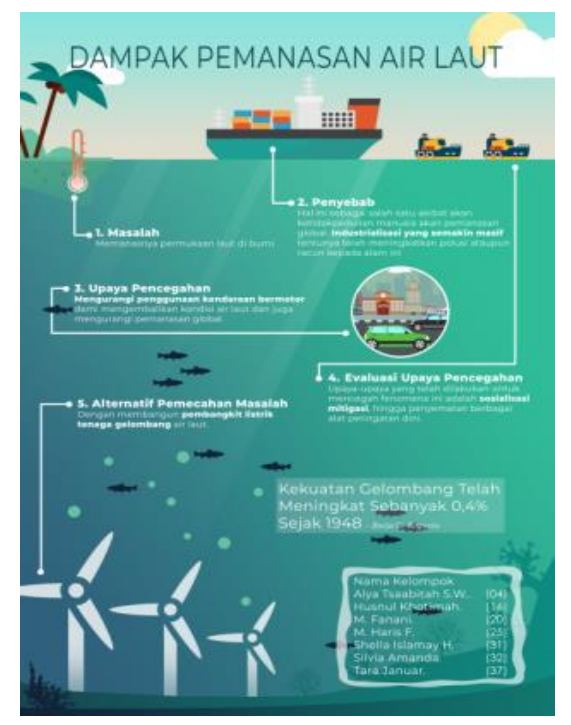

Fig 1. Digital Poster by Class 1

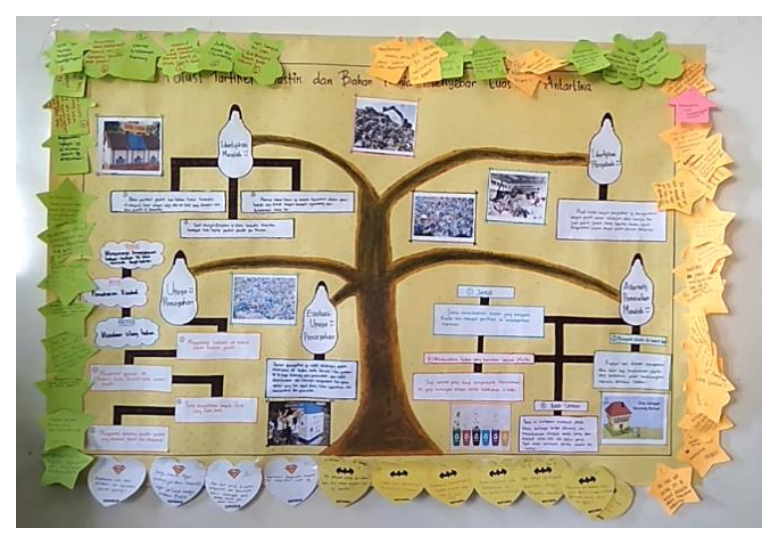

Fig 2. Manual Poster by Class 2 
The Results of Poster Assessment

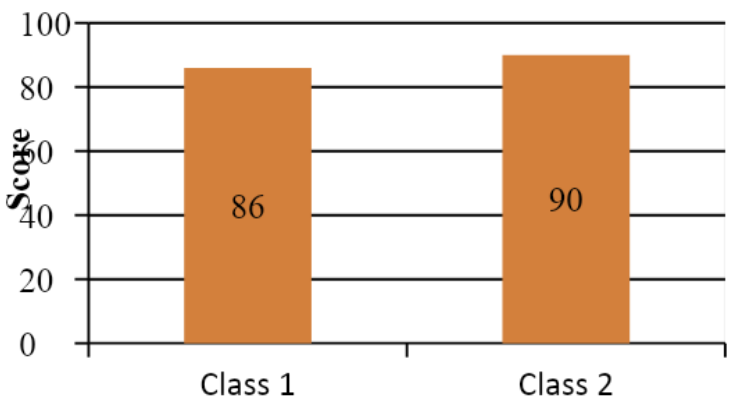

Fig 3. The results of the poster assessment

TABLE 2. THE RESULTS OF OBSERVATION

\begin{tabular}{cc|ccc}
\hline Indicator & \multicolumn{2}{c}{ Class 1 } & \multicolumn{2}{c}{ Class 2 } \\
\cline { 2 - 5 } & Pre (\%) & Post (\%) & Pre) & Post (\%) \\
\hline Fluency & 70 & 92 & 66 & 94 \\
\hline Flexibility & 54 & 76 & 74 & 86 \\
\hline Originality & 76 & 90 & 60 & 84 \\
\hline Elaboration & 78 & & 66 & 88 \\
\hline
\end{tabular}

TABLE 3. THE RESULTS OF QUESTIONNAIRE

\begin{tabular}{cllccc}
\hline \multirow{2}{*}{ No } & \multicolumn{1}{c}{ Statement } & \multicolumn{2}{c}{ Class 1 } & \multicolumn{2}{c}{ Class 2 } \\
\cline { 3 - 6 } & & $\mathbf{\%}$ & Category & $\mathbf{\%}$ & Category \\
\hline 1 & I enjoy the learning activity & 80 & Agree & 84 & Very agree \\
2 & I feel happy to learn physics because the learning activity is interesting & 80 & Agree & 88 & Very agree \\
3 & I become more active during the class & 74 & Agree & 82 & Very agree \\
4 & This method gives chances me to know my deficiencies and revise it & 84 & Very agree & 88 & Very agree \\
5 & This method makes the class be more fun and not bored & 82 & Very agree & 88 & Very agree \\
6 & I feel more confident to express my opinions during the class & 74 & Agree & 84 & Very agree \\
7 & This method makes it easier to express my opinions & 84 & Very agree & 88 & Very agree \\
8 & I can collaborate well during class and doing the group assignment & 84 & Very agree & 86 & Very agree \\
9 & The assignment is able to develop my creativity skill & 80 & Agree & 88 & Very agree \\
10 & I am able to correlate the concept with other disciplinaries (such as biology, & 78 & Agree & 82 & Very agree \\
\hline & chemistry, economy etc) & & & & \\
\hline
\end{tabular}

In the 20th century, teachers have preferred to use a variety of means to assess creativity, by monitoring students' work, behaviour and what they said [26]. However, as Fryer (1996) noted when considering the creativity of school students, there are some problems with such taxonomies of criteria. In Fryer's study of 1,000 teachers, most of them preferred judging students' work against each individual's past performance. Thus something might be deemed to be original for a particular student. Training in creative problem solving can enable people to be skilled in finding the best solution quickly [27].

The implementation of PBL with Gallery Walk strategy was conducted to two classes that had the same cognitive level. It was based on the pretest that was given on the preliminary. Based on the observation results in table 2, it can be observed that was enhancement percentage in each aspect of creativity. Pre-observation was conducted when the students were teaching by the physics teacher before the treatment given. Post-observation data was collected when the treatment given, the researchers were implementing the teaching method. The enhancement percentage of class 2 was more significant than class 1 . The fluency of class 2 was the highest scores from all creativity aspects that were $94 \%$. Fluency described the curiosity students in the class [7,8]. It meant class 2 was more active and had more questions than class 1 . Less than $10 \%$ of the students became passive learners. Flexibility is the ability to produce a large variety of ideas [8]. Students were not searching for a particular answer or the teacher's "correct" view; students were free to consider many ideas and perspectives. For flexibility, class 1 got higher enhancement than class 2 . It enhanced by about $32 \%$. It showed that class 1 got more various answer. Instead, class 2 got a higher enhancement for elaboration and originality. The enhancement was up to $20 \%$. Elaboration is the ability to develop, embellish or fill out an idea [8]. Other words, originality is the ability to produce ideas that are unusual, statistically infrequent, not banal or obvious [8]. According

the observation, it showed that students communication enhanced when the method was applied. It showed the number of students who were more active during the class. 
Students were more confident to express their opinions and questions during the discussion, especially when the exhibition. Supported by their internal motivation to collect more point by giving opinions in each stand, students were talk-active. In this stage, the competitive atmosphere showed up. Motivation is one of six sources that identified as facilitating creativity [28]. Sternberg and Lubart (1991) also indicated that there are two types of motivation important to creativity: intrinsic motivation and external motivation. Intrinsic motivation was motivation from internal factor to complete the assignments and get the best score [29].

The results were supported by the results of the questionnaire. The questionnaire showed that the students were more active in class, which was $74 \%$ for class 1 and $82 \%$ for class 2. Students also enjoyed the learning activity. Students also agreed that the learning activities were interesting, it makes the atmosphere in class was fun and not boring. It made students were easier to express their opinions during the class both oral and written. More than $80 \%$ of students agreed that this method gave chances to know their deficiencies and revise it. This method was conducted in a small group, therefore students should be able to collaborate with other students. About $84 \%$ of class 1 and $86 \%$ of class 2 agreed that they were able to collaborate in their groups well. In this stage, students had to adapt to their group and communicate well. In results, students got the best results of them. The assignment was designed to develop their creativity and HOTS. Because, students had to analysis the problems, then evaluate and create ideas to solve the problems. It was $88 \%$ of students who agreed that it can develop their creativity in class 2 . While in class 1 , it was $4 \%$ lower than class 2 . Students also agreed that they were able to correlate the concept with other disciplinary, such as biology, chemistry, economy and etc. More specifically, the percentage of class 1 was $78 \%$ in the 'agree' category and class 2 was $82 \%$ in 'very agree' category. After all, class 2 got a higher percentage than class 1 , which was $86 \%$ in 'very good' category. For class 1, it was $80 \%$ in the 'good' category.

Based on observation and questionnaire, students were more active and confident to express their ideas and opinions. Students were also more critical in class. There was an enhancement in pre and post-observation. Based on table 1, the fluency, flexibility and elaboration in the post were categorized in very agree and originality was categorized in agree for both experimental classes. For fluency, flexibility and elaboration, class 1 was higher than class 2 . While originality, class 2 was higher than class 1 . It could be caused by class 2 used manual posters that designed and made by drawing, cutting and sticking. For poster assessment, it showed that the average score of class 1 and 2 was 86 and 90 . Class 2 got higher scores than class 1 . It showed the user of the manual poster was more effective than the digital poster. It caused more senses you use, the deeper the information embedded $[15,30]$. In making the manual poster, students used more senses than in digital poster. Besides that, in the manual poster, a student was freer and more original to design than using digital technology. The probability of plagiarism in the digital poster was also higher than the manual poster.
The results showed that the implementation of PBL with Gallery Walk strategy was able to enhance the creativity and communication skill of students. Using manual poster was more effective to enhance creativity and communication skills of students. The constraint in this research was the management class. Especially in the exhibition, students were more talk active and the class is crowded. Teachers have to direct the discussion to the topic and control it not until overcrowded. Besides, the teacher should have good relationships with students to build a fun atmosphere in class. Because these methods use a lot of interaction both peer students or teacher in the learning activities.

\section{DISCUSSION}

Based on the results and discussion, it can be concluded that the implementation of PBL with Gallery Walk strategy was able to enhance creativity and communication skills. Students became more active during the learning activities. As a result, it increased the students' participation. Using manual poster was more effective to enhance creativity and communication skills of students.

\section{REFERENCE}

[1] B, Trilling \& C, Fadel, '21st-century skills: learning for life in our times”, Jossey-Bass: San Francisco:’, 2009.

[2] H M Huang, 'Toward constructivism for adult learners in online learning environment", British Journal of Educational Technology", vol. 33, pp. 27-37, 2002

[3] H G Jellen \& K K, "'Assessing creative potential world-wide: The first cross-cultural application of the Test for Creative ThinkingDrawing Production (TCT-DP)", Gifted Education International, vol. 6, no. 2, pp. 78-86, 1989.

[4] M B Karnes, G. F McCoy, R R Zehrbach, J P Wollersheim, H F Clarizio, L Costin \& L S Stanley, "Factors associated with underachievement and overachievement of intellectually gifted children", Champaign IL: Champaign Community Unit Schools, 1961.

[5] R W Woodman \& L F Schoenfeldt, " Handbook of Creativity (3rd Edition) (New York: Spriger Business Media)", 1989.

[6] D Supriadi, 'Kreativitas, kebudayaan dan perkembangan Iptek", Bandung: Alfabeta, 2002.

[7] Munandar U, "Pengembangan kreativitas anak berbakat", Jakarta: Rineka Cipta, 2002.

[8] E P Torrance, "Education and the creative potential", Minneapolis: University of Minnesota Press, 1963.

[9] Davis G A and Rimm S B, "Education of the gifted and talented", Englewood Cliffs: Prentice Hall, 1985.

[10] R F Subotnik, "Factors from the structure of intellect model associated with gifted adolescents' problem finding in science Journal of Creative Behavior', vol. 22, pp. 42-54, 1988.

[11] G A Davis, "Teaching creativity thinking. In N. Colangelo \& G. A. Davis (Eds.)", Handbook of gifted education (Boston: Allyn \& Bacon), 1991.

[12] J P Guilford, "'Creativity American Psychologist", vol. 5, pp. 444454, 1989

[13] J F Feldhusen \& D J Treffinger, 'Creative thinking and problem solving in gifted education", Dubuque: Kendall/Hunt , 1980.

[14] Indonesian Ministry of Education and Culture 2013 Peraturan Menteri Pendidikan No. 65 tentang Standar Proses Pendidikan Dasar dan Menengah", Jakarta: Indonesian Ministry of Education and Culture.

[15] R I Arends, 'Learning to Teach (9th Edition)", New York: McGraw-Hill, 2012

[16] E.F Momo \& S Wahyu, 'Skill analysis of students' creative thinking in implementation of problem based learning with plastic waste handling context", Surabaya: Institute of Physics (IOP) Publishing, pp 1-5, 2015. 
[17] Y N Widhitama, A Lukito \& S Khabibah, "Problem solving-based learning materials on fraction for training creativity of elementary school students", Surabaya: Institute of Physics (IOP) Publishing, pp. $1-5,2015$

[18] S L Bowman, "The gallery walk: an opening, closing and review activity", Glenbrook: Bowperson Publishing, 2005.

[19] C Allen and J Larmer, 'Using Gallery Walks for Revision and Reflection (Boston: Buck Institute for Education (BIE)", 2015.

[20] A Setyawati, M Syafar, A Majid and R Rachmawati ,'The effectiveness of Paired-Share Gallery Walk (PSGW) on students' Critical Appraisal Skill (CAS) improvement during the medical surgical nursing clinical placement", Journal INJEC, vol.2, pp. 184192, 2017.

[21] C S Pertiwi, L Lestari and I R Atmojo, 'The implementation og gallery walk learning model to improve verbal communicating skill of performance result thru thematic learning", Semarang: Universitas Sebelas Maret, pp. 151-158, 2018.

[22] D W Rodenbaugh, "Maximize a team-based learning gallery walk experience : herding cats is easier than you think", the United States: American Psycologycal Society", pp. 411-413, 2015.
[23] C K Chin, K H Khor, \& T K The, "' Is gallery walk an effective teaching and learning strategy for biology?", Kuala Lumpur: Springer', pp. 55-59, 2015.

[24] Nurlaili S, "Efektivitas model pembelajaran kooperatif tipe gallery walk ditinjau dari pemahaman konsep matematis siswa", Bandar Lampung: Universitas Lampung, 2017.

[25] D A Septiana, 'The implementation of problem based learning with gallery walk strategy on global warming", IPF: Inovasi Pendidikan Fisika, vol. 8, pp. 692-695, 2019

[26] M Fryer, "Creative teaching and learning", London: Paul Chapman Publishing Ltd, 1996.

[27] D Jr Fasko, " Education and creativity", Creativity Reserch Journal, vol. 13, pp. 317-327, 2017.

[28] R J Sternberg and T I Lubart, 'Creating creative minds", Phi Delta Kappan, vol. 72, pp. 608-614, 1991.

[29] B A Hennessey and T M Amabile, "Creativity and learning", Washington DC: NEA Professional Library, 1987.

[30] Rusman, "Belajar dan pembelajaran: berorientasi standar proses pendidikan", Jakarta: Kencana, 2017. 